\title{
Correction to: Transient expression of SbDhr2 and MeHNL in Gossypium hirsutum for herbivore deterrence assay with Spodoptera litura
}

\author{
MAHAJAN Chavi $i^{*}$, NASER Rafiuddin ${ }^{1}$, RAWAL Shuban ${ }^{2}$, PYATI Prashant ${ }^{2}$, PANDA Bhuban ${ }^{2}$, \\ LOMATE Purushottam ${ }^{2}$ and GUPTA Shantikumar ${ }^{3}$
}

\author{
Correction to: J Cotton Res 3, 2 (2020) \\ https://doi.org/10.1186/s42397-020-0044-z
}

We would like to correct the authorship of our article (Mahajan et al. 2020) to include RAWAL Shuban, PYATI Prashant, PANDA Bhuban and LOMATE Purushottam. The updated authorship, affiliations and contributions can be seen below.

Also, we would like to gratefully acknowledge Mr. Sameer MULAY, Managing Director of Ajeet Seeds Pvt. Ltd. for providing resources to carry out the research at Plant Biotechnology Research Centre, Gangapur.

Authorship

MAHAJAN Chavi 1, NASER Rafiuddin 1, RAWAL Shuban 2, PYATI Prashant 2, PANDA Bhuban 2, LOMATE Purushottam 2, GUPTA Shantikumar 3

Affiliations

1. Department of Botany, Maulana Azad College of Arts Science and Commerce, Rauza Bagh, Aurangabad, Maharashtra, 431001, India.

2. Plant Biotechnology Research Centre, Ajeet Seeds Pvt. Ltd. Gangapur, Aurangabad, Maharashtra, 431001, India.

3. Government Institute of Science, Aurangabad, Maharashtra, 431001, India.

Contributions
Mahajan C conducted this study for his Ph.D. research. He was involved with conceptualization, data curation, formal analysis, investigation, methodology, validation, writing - original draft and rewriting - review editing of this manuscript. Rawal S helped with conceptualization, the investigation, validation, overall supervision along with critical assessment of the study. Pyati $\mathrm{P}$ helped with conceptualization and methodology. Panda B and Lomate $P$ helped with the methodology. Naser $R$ as supervisor and GUPTA S as co-supervisor helped with validation, writing - original draft and rewriting - review \& editing of this manuscript. All the authors read and approved the final manuscript.

\section{Author details}

${ }^{1}$ Department of Botany, Maulana Azad College of Arts Science and Commerce, Rauza Bagh, Aurangabad, Maharashtra 431001, India. ${ }^{2}$ Plant Biotechnology Research Centre, Ajeet Seeds Pvt. Ltd., Gangapur, Aurangabad, Maharashtra 431001, India. ${ }^{3}$ Government Institute of Science, Aurangabad, Maharashtra 431001, India.

Published online: 13 August 2020

\section{Reference \\ Mahajan C, Naser R, Gupta S. Transient expression of SbDhr2 and MeHNL in Gossypium hirsutum for herbivore deterrence assay with Spodoptera litura. J Cotton Res. 2020;3:2. https://doi.org/10.1186/s42397-020-0044-z.}

(c) The Author(s). 2020 Open Access This article is licensed under a Creative Commons Attribution 4.0 International License, which permits use, sharing, adaptation, distribution and reproduction in any medium or format, as long as you give appropriate credit to the original author(s) and the source, provide a link to the Creative Commons licence, and indicate if changes were made. The images or other third party material in this article are included in the article's Creative Commons licence, unless indicated otherwise in a credit line to the material. If material is not included in the article's Creative Commons licence and your intended use is not permitted by statutory regulation or exceeds the permitted use, you will need to obtain permission directly from the copyright holder. To view a copy of this licence, visit http://creativecommons.org/licenses/by/4.0/. 